\title{
Pemanfaatan Rhizobakteri dari Gulma di UB Forest sebagai Agen Antagonis Penyakit Layu Bakteri pada Kentang
}

\author{
Junda Fauzul Izza ${ }^{1)}$, Luqman Qurata Aini' ${ }^{2}$, Restu Rizkyta Kusuma ${ }^{3)}$ \\ ${ }^{1,2,3)}$ Jurusan Hama dan Penyakit Tumbuhan, Fakultas Pertanian, Universitas Brawijaya \\ ${ }^{1)}$ Alamat korespondensi: jundafizza@gmail.com
}

\begin{abstract}
ABSTRAK
Penyakit layu bakteri yang diakibatkan oleh patogen Ralstonia solanacearum merupakan kendala yang sering terjadi pada budidaya tanaman kentang. Penelitian bertujuan untuk mendapatkan rhizobakteri yang efektif mengendalikan penyakit layu bakteri dan meningkatkan pertumbuhan pada tanaman kentang. Penelitian dilaksanakan di Laboratorium Penyakit Tumbuhan Fakultas Pertanian Universitas Brawijaya, UB Forest, dan Desa Tulungrejo Kecamatan Bumiaji, Kota Batu. Rhizobakteri diisolasi dari perakaran gulma di UB Forest kemudian dilakukan pengujian aktivitas sebagai pemicu pertumbuhan. Rhizobakteri yang terpilih dilakukan pengujian sifat antagonis terhadap $R$. solanacearum secara in vitro dan penekanan terhadap angka kejadian penyakit serta pertumbuhan tanaman kentang. Identifikasi isolat dilakukan secara fisiologi, biokimia dan molekuler. Hasil eksplorasi didapatkan 20 isolat rhizobakteri yang bersifat antagonis terhadap $R$. solanacearum. Isolat AGR 2 memiliki diameter penghambatan yang sama dengan bakterisida secara in vitro. Secara in vivo isolat bakteri AGR 1, AGR 2 dan EPT 9 dapat meningkatkan rerata jumlah daun lebih tinggi dibandingkan dengan bakterisida pada 1 dan 2 MSA (minggu setelah aplikasi). EPT 9 mampu menekan angka kejadian penyakit layu bakteri 55,6 \% setelah 5 MSA dan meningkatkan berat umbi sebesar 59,3 \% lebih tinggi dari perlakuan kontrol. Isolat AGR 2 diketahui sebagai Pseudomonas aeruginosa dan EPT 9 merupakan Bacillus cereus.
\end{abstract}

Kata Kunci: Bacillus, kentang, layu bakteri, Pseudomonas, 16s rRNA,

\section{Utilization Rhizobacteria on Weeds in UB Forest as Antagonistic Agents to Bacterial Wilt in Potato}

\author{
Junda Fauzul Izza ${ }^{1{ }^{*}}$, Luqman Qurata Aini ${ }^{2)}$, Restu Rizkyta Kusuma ${ }^{3)}$ \\ Jurusan Hama dan Penyakit Tumbuhan, Fakultas Pertanian, Universitas Brawijaya \\ *)Email: jundafizza@gmail.com
}

\begin{abstract}
Bacterial wilt disease caused by pathogen Ralstonia solanacearum has created severe problem mainly on potato. The aim of this research was to obtain rhizobacteria isolates, which were effective to control bacterial wilt disease and promote plant growth in potato. Research was conducted in Plant Disease Laboratory, UB Forest and Tulungrejo, Bumiaji, Malang. Rhizosphere soils were derived from plant roots in UB Forest and the isolated bacteria were tested for their plant growth promotion attributes. Selected rhizobacteria then tested to against $R$. solanacearum in vitro test, suppressing disease incident and for their abilities in plant growth on potato performance. Isolated bacteria were identified based on physiology, biochemistry and molecular. The results showed that 20 rhizobacteria isolates were antagonistic to $R$. solanacearum. AGR 2 has inhibition zone similar to bactericide in vitro trials. AGR 1, AGR 2 and EPT 9 isolates increased leaves amount higher than bactericide at 1 to 2 MSA. EPT 9 suppressed bacterial wilt disease $55.6 \%$ after five weeks of application and tuber production was increased by $59,3 \%$ compared to control. AGR 2 was identified as Pseudomonas aeruginosa and EPT 9 was Bacillus cereus.
\end{abstract}

Keywords: Bacillus, bacterial wilt, potato, Pseudomonas, 16s rRNA 


\section{PENDAHULUAN}

Kentang termasuk komoditas hortikultura yang memiliki rerata produksi cukup besar dibandingkan dengan komoditas lainnya [1]. Produksi tanaman kentang melebihi 350 juta ton pertahun [2]. Namun produksi kentang dalam negeri hanya mampu memenuhi $25 \%$ dari kebutuhan domestik [3].

Salah satu kendala dalam produksi tanaman kentang yaitu penyakit layu yang diakibatkan oleh patogen Ralstonia solanacearum. Serangan $R$. solanacearum menyebabkan daun-daun muda layu yang diikuti dengan layu pada seluruh bagian tanaman. Dewasa ini, teknologi yang dikembangkan untuk mengendalikan penyakit layu bakteri pada kentang didasarkan kepada konsep pengendalian hama terpadu (PHT). Pengendalian menggunakan agens hayati merupakan metode alternatif untuk mengatasi beberapa hambatan tersebut.

Rhizobakteri merupakan bakteri yang berkolonisasi di daerah perakaran dan membentuk hubungan simbiotik terhadap tanaman. Rhizobakteri seringkali disebut sebagai plant growth promoting rhizobacteria (PGPR) untuk memicu pertumbuhan tanaman. Rhizobakteri dapat dimanfaatkan sebagai agens hayati. Penggunaan PGPR sebagai agens hayati patogen tular tanah merupakan strategi alternatif dari pengendalian penyakit [4].

UB Forest merupakan kawasan hutan pendidikan yang terletak di kawasan gunung Arjuna, Malang. Hutan ini merupakan kawasan hutan tropis yang memiliki sumber keragaman yang tinggi. Oleh karena itu, komunitas mikroba tanah yang ditemukan seperti pada rhizosfer, diharapkan cenderung lebih komplek daripada di lokasi lain.

Keragaman flora seperti tumbuhan merupakan salah satu karakteristik dari hutan tropis. Ketersediaan tumbuhan khususnya dari Famili Asteraceae seperti Ageratum conzoides, Eupatorium odoratum, dan Famili Solanaceae yaitu Brugmansia sp. tumbuh melimpah di kawasan UB Forest.

Sampel tanah dalam penelitian ini akan diisolasi dari sekitar perakaran gulma family Asteraceae dan Solanaceae. Gulma tersebut merupakan salah satu inang dari $R$. solanacearum namun, gejala serangan yang diakibatkan tidak berpengaruh diduga karena adanya aktivitas antimikroba. Penelitian bertujuan untuk mendapatkan rhizobakteri yang efektif mengendalikan penyakit layu bakteri dan meningkatkan pertumbuhan kentang.

\section{METODE PENELITIAN}

Penelitian dilaksanakan pada bulan Laboratorium Penyakit Tumbuhan, Desember 2017 hingga Mei 2018 di Fakultas Pertanian, Universitas Brawijaya, Malang dan di Desa Tulungrejo, Bumiaji, Malang.

Pengambilan sampel tanah rhizosfer. Pengambilan sampel tanah dilakukan di UB Forest. Tanah diambil pada beberapa titik representatif di sekitar perakaran gulma $A$. conyzoides, Brugmansia sp., dan E. Odoratum dengan kedalaman $10 \mathrm{~cm}$. Masing-masing sampel tanah disimpan dalam wadah plastik kemudian dibawa ke laboratorium untuk perlakuan berikutnya.

Isolasi rhizobakteri dari UB Forest. Metode isolasi dilakukan dengan menggunakan metode pengenceran. Satu gram sampel tanah dimasukkan kedalam $9 \mathrm{~mL}$ akuades steril dan dihomogenkan. Selanjutnya dilakukan pengenceran berseri dengan memindahkan $1 \mathrm{~mL}$ suspensi sampel ke dalam $9 \mathrm{~mL}$ akuades steril. Langkah ini dilanjutkan hingga pengenceran $10^{9}$. Suspensi bakteri hasil pengenceran diambil sebanyak $0,1 \mathrm{~mL}$ dan diinokulasikan ke media nutrient agar (NA) dengan metode spread plate. Medium terinokulasi diinkubasi selama 24-48 jam pada suhu ruangan. Koloni yang tumbuh dimurnikan dengan metode streak plate hingga mendapatkan isolat murni. Kemurnian isolat dikonfirmasi dengan pengamatan secara morfologi dengan mikroskop [5].

Uji Patogenisitas. Uji patogenisitas dilakukan untuk mengetahui virulensi bakteri patogen. Bakteri patogen $R$. solanacearum diperoleh dari koleksi Laboratorium Penyakit Tumbuhan, Fakultas Pertanian Universitas Brawijaya. Uji patogenisitas dilakukan pada bibit kentang varietas Granuola berumur 1 bulan menggunakan biakan murni bakteri patogen $R$. solanacearum berumur 24 jam. Biakan murni dibuat suspensi dengan melarutkan beberapa ose bakteri dalam $10 \mathrm{~mL}$ akuades steril. Kemudian 10 $\mathrm{mL}$ suspensi bakteri $R$. solanacearum $10^{9} \mathrm{cfu} / \mathrm{ml}$ disiram ke akar bibit kentang yang telah dilukai akarnya menggunakan skalpel [6]. Gejala yang timbul pada tanaman sehat setelah inokulasi harus 
sama dengan gejala serangan $R$. solanacearum di alam.

Seleksi isolat bakteri antagonis. Bakteri rhizosfer yang telah diisolasi selanjutnya diuji sifat antagonis yang mengacu pada metode yang dilakukan Kawaguchi [7]. Kertas saring steril berdiameter $5 \mathrm{~mm}$ dicelupkan dalam suspensi bakteri selama 1 menit dan ditiriskan selama 2 jam. Kertas tersebut diletakkan pada media NA kemudian diinkubasi selama 24 jam pada suhu $27-30{ }^{\circ} \mathrm{C}$. Setelah inkubasi, isolat bakteri dimatikan dengan menambahkan kloroform $1 \mathrm{~mL}$ pada tutup cawan Petri dalam keadaan dibalik dan didiamkan selama 2 jam hingga menguap. Setelah itu, biakan dikabutkan (spray) dengan suspensi bakteri patogen $R$. solanacearum. Setelah inkubasi 24-48 jam, diamati pembentukan zona bening di sekitar kertas saring. Pada isolat yang terdapat zona bening akan digunakan untuk pengujian selanjutnya.

Pengujian aktivitas plant growth promoting (PGP). Isolat yang mempunyai kemampuan antagonis kemudian diuji perannya sebagai pemicu pertumbuhan tanaman sebagai berikut [8]:

Aktivitas pelarut fosfat. Aktivitas pelarutan fosfat dapat diketahui dengan mengukur halozone atau zona bening akan terbentuk disekitar koloni yang ditumbuhkan dengan streak plate dalam suhu ruangan di media Pikovskaya. Medium agar Pikovskaya tersusun dari 1 liter akuades, ekstrak ragi 0,5 g, dextrose $10 \mathrm{~g}$, $\mathrm{Ca}_{3}\left(\mathrm{PO}_{4}\right)_{2} 5,0 \mathrm{~g},\left(\mathrm{NH}_{4}\right)_{2} \mathrm{SO}_{4} 0,50 \mathrm{~g}, \mathrm{KCl} 0,2 \mathrm{~g}$, $\mathrm{MgSO}_{4} \quad 0,10 \mathrm{~g}, \mathrm{MnSO}_{4} 0,0001 \mathrm{~g}, \mathrm{FeSO}_{4}$ $0,0001 \mathrm{~g}$, agar $15 \mathrm{~g}$.

Aktivitas penambat Nitrogen. Uji penambatan Nitrogen dilakukan pada media Burk. Komposisi media Burk adalah garam Burk 1,3 g, agar 15 g, Fe-Mo $1 \mathrm{~mL}$, sukrosa 20 $\mathrm{g}$ dan akuades $1 \mathrm{~L}$. Garam Burk tersusun dari $\mathrm{MgSO}_{4} 20$ g, $\mathrm{K}_{2} \mathrm{HPO}_{4} 80$ g, $\mathrm{KH}_{2} \mathrm{PO}_{4} 20 \mathrm{~g}$, $\mathrm{CaSO}_{4} 13 \mathrm{~g}$, sedangkan Fe-Mo terdiri dari $\mathrm{FeCl}_{3} 1,45 \mathrm{~g}, \mathrm{NaMoO}_{4}(0,253 \mathrm{~g}$, akuades $1 \mathrm{~L}$. Isolat yang mampu tumbuh pada media tersebut menunjukkan bahwa isolat mampu menambat Nitrogen.
Uji Hipersensitif. Uji hipersensitif dilakukan dengan melukai permukaan daun tembakau dengan memasukkan $5 \mathrm{~mL}$ suspensi bakteri menggunakan jarum suntik. Jika pada bagian inokulasi terjadi nekrosis setelah 24 hingga 72 jam, maka isolat tergolong bakteri patogen terhadap tumbuhan.

Uji Antagonis terhadap Pertumbuhan $R$. solanacearum secara In Vitro. Pemilihan isolat didasarkan atas sifat PGP dan sifat antagonis yang besar terhadap patogen pada pengujian sebelumnya. Uji antagonis secara in vitro menggunakan rancangan acak kelompok (RAK) terdiri dari 6 perlakuan yaitu 1 kontrol positif menggunakan bakterisida streptomysin sulfat dan 5 isolat bakteri terpilih dengan 4 ulangan. Variabel pengamatan pada pengujian ini yaitu persentase tingkat penghambatan pertumbuhan $R$. solanacearum oleh bakteri antagonis yang diisolasi dari UB Forest. Rumus yang digunakan yaitu:

$$
\mathrm{DP}=\frac{\mathrm{DH}+\mathrm{DV}}{2}
$$

Keterangan:

$\begin{array}{ll}\mathrm{DH} & =\text { diameter daya hambat }(\mathrm{cm}) \\ \mathrm{DH} & =\text { diameter horizontal }(\mathrm{cm}) \\ \mathrm{DV} & =\text { diameter vertikal }(\mathrm{cm})\end{array}$

Uji Penekanan Penyakit Layu Bakteri secara In Vivo. Pelaksanaan uji secara in vivo dilakukan di lahan Desa Tulungrejo, Bumiaji, Malang. Lokasi tersebut merupakan daerah endemis $R$. solanacearum pada kentang, sehingga inokulasi patogen tidak dilakukan. Bibit tanaman kentang yang digunakan yaitu varietas Granuola. Pengujian antagonis di lapang menggunakan suspensi isolat bakteri rhizosfer pada konsentrasi $10^{8} \mathrm{cfu} / \mathrm{ml}$ yang diaplikasikan ke media tanam [9]. Percobaan dilakukan di lahan menggunakan RAK sebanyak 7 perlakuan dan 4 ulangan (5 perlakuan rhizobakteri, 1 kontrol menggunakan akuades dan 1 menggunakan bakterisida).

Aplikasi rhizobakteri dilakukan dengan menyiramkan suspensi pada tanaman kentang yang berumur 4 minggu setelah tanam [10]. Suspensi rhizobakter diberikan ke masing-masing tanaman sebanyak $50 \mathrm{ml}$. Inokulasi rhizobakteri dilakukan pada tanaman berumur 1 bulan 
kemudian aplikasi kedua dilakukan 2 minggu setelah aplikasi pertama.

Variabel pengamatan. Pengamatan dilakukan sekali dalam seminggu setelah aplikasi sampai masuk fase generatif. Variabel yang diamati yaitu tinggi tanaman, jumlah daun, berat umbi dan persentase kejadian penyakit. Kejadian penyakit dihitung dengan menggunakan rumus:

Persentase kejadian penyakit

$$
\mathrm{IP}=\frac{a}{a+b} \times 100(\%)
$$

Keterangan

$\mathrm{IP}=$ Intensitas serangan penyakit

$\mathrm{a}=$ Jumlah tanaman sakit

$\mathrm{b}=$ Jumlah tanaman sehat

Identifikasi Bakteri Hasil Seleksi. Identifikasi bakteri dilakukan dengan pedoman buku Bergey's Determinative Bacteriology [11][12] dan identifikasi molekuler berdasarkan hasil sekuensing gen 16S rRNA. Primer yang digunakan adalah primer uinF (5'AGAGTTTGATCATGGGTCAG-3') dan uinR (5'- TACGGCTACCTTGTTACGA-3') yang merupakan primer universal untuk berbagai strain bakteri. produk PCR kemudian disekuensing untuk mendapatkan susunan basa DNA. Sekuens basa DNA tersebut kemudian dibandingkan dengan sekuens DNA yang terdapat pada gen bank NCBI untuk mencari kemiripan dengan spesies bakteri tertentu, dengan menggunakan program BLAST dari NCBI.

Analisis Data. Hasil pengamatan dianalisis secara statistik menggunakan analisis ragam ANOVA dan apabila terdapat perbedaan nyata akan diuji lanjut dengan uji Duncan (DMRT) pada taraf kesalahan 5\%.

\section{HASIL DAN PEMBAHASAN}

Eksplorasi dan Isolasi Rhizobakteri. Telah diperoleh 38 isolat dari eksplorasi pada 3 jenis gulma. Sebanyak 14 isolat bakteri berasal dari gulma $A$. conyzoides dan diberi kode AGR, sedangkan dari gulma E. odoratum (kode EPT) dan Brugmansia sp. (kode BR) diperoleh 9 dan 15 isolat secara berturut-turut.

Uji Patogenisitas. Gejala penyakit layu bakteri yang disebabkan patogen $R$. solanacearum muncul 2 minggu setelah aplikasi. Gejala awal menunjukkan daun nekrotik kemudian menjadi layu dan batang bawah mengalami perubahan warna menjadi coklat setelah 2 minggu aplikasi. Gejala yang muncul menunjukkan gejala yang sama dengan yang ditemukan di alam [13].

Pengujian Aktivitas PGP. Isolat bakteri yang mempunyai potensi melarutkan fosfat terdiri dari 3 isolat yang diisolasi dari rhizosfer tumbuhan $A$. conyzoides, 1 isolat dari tumbuhan $E$. odoratum dan 3 isolat dari Brugmansia sp. Potensi tersebut ditandai dengan terbentuknya zona bening pada medium agar Pikovskaya. Zona bening yang terbentuk di sekitar koloni bakteri tersebut dikarenakan adanya produksi enzim fosfatase untuk melarutkan fosfat [14].

Berdasarkan hasil pengujian didapatkan 16 isolat bakteri yang mampu tumbuh pada media Burk. Bakteri tersebut merupakan bakteri yang dapat menambat nitrogen karena memiliki enzim nitrogenase yang akan membantu mengikat $\mathrm{N}_{2}$ bebas di udara [15].

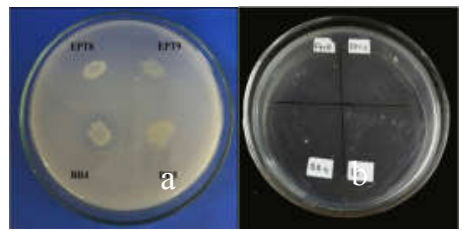

Gambar 1. Hasil seleksi isolat bakteri. (a) Pelarut fosfat pada media Pikovskaya, (b) Penambat nitrogen pada media Burk

\section{Hasil Pengujian Hipersensitif.} Berdasarkan hasil uji hipersensitif isolat bakteri menimbulkan reaksi negatif yaitu tidak menimbulkan gejala nekrotik di sekitar area injeksi. Tidak munculnya gejala nekrotik pada daun tembakau menunjukkan bahwa isolat bakteri tersebut diduga tidak bersifat patogenik terhadap tanaman, sedangkan daun yang menunjukkan perubahan warna (nekrotik) di daerah inokulasi diduga bersifat patogenik terhadap tanaman [16].

\section{Uji Antagonisme Bakteri Rhizosfer} terhadap Pertumbuhan Patogen $R$. Solanacearum secara In Vitr. Pengujian antagonisme dilakukan terhadap 5 isolat terpilih. Diameter penghambatan bakteri antagonis terhadap pertumbuhan bakteri patogen $R$. solanacearum ditampilkan pada Tabel 1. 
Tabel 1. Diameter penghambatan bakteri antagonis

\begin{tabular}{ll}
\hline Perlakuan & $\begin{array}{l}\text { Diameter hambat } \\
(\mathrm{cm}) \pm \mathrm{SD}\end{array}$ \\
\hline P1 (bakterisida & \\
streptomisin sulfat) & $3,08 \pm 0,12^{\mathrm{b}}$ \\
P2 (isolat AGR1) & $2,83 \pm 0,68^{\mathrm{b}}$ \\
P3 (isolat AGR 2) & $3,28 \pm 0,24^{\mathrm{b}}$ \\
P4 (isolat EPT 8) & $2,85 \pm 0,67^{\mathrm{b}}$ \\
P5 (isolat EPT 9) & $2,20 \pm 0,17^{\mathrm{a}}$ \\
P6 (isolat AGR 9) & $1,90 \pm 0,27^{\mathrm{a}}$ \\
\hline
\end{tabular}

Keterangan: Angka yang diikuti dengan huruf yang sama dalam satu kolom menunjukkan hasil yang tidak berbeda nyata berdasarkan uji DMRT pada taraf $5 \%$.

Berdasarkan hasil pengujian, diketahui bahwa isolat AGR 1, AGR 2, EPT 8 memiliki diameter penghambatan yang mirip dengan bakterisida streptomysin sulfat. Diameter penghambatan berupa zona bening menunjukkan terhambatnya pathogen $R$. solanacearum akibat senyawa antibiotik yang dikeluarkan oleh bakteri. Senyawa antibiotik tersebut dapat berupa siderofor, enzim litik, enzim detoksifikasi maupun senyawa kimia (alelokimia) yang dapat merusak virulensi patogen [17].
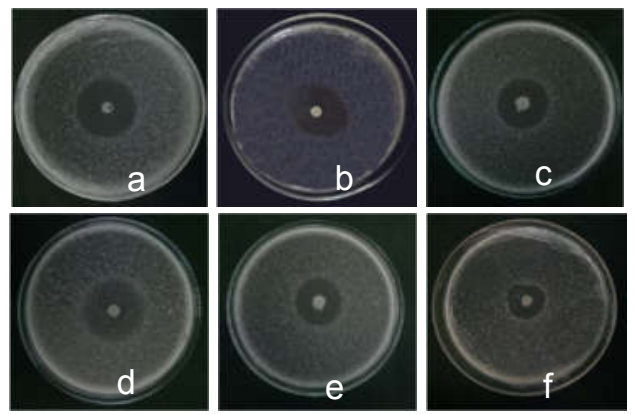

Gambar 2. Zona bening yang dihasilkan oleh setiap perlakuan setelah 24 jam inkubasi pada media NA. (a) bakterisida streptomisin sulfat, (b) isolat AGR 1, (c) Isolat AGR 2, (d) EPT 8, (e) EPT 9, (f) AGR 9

Uji Penekanan Penyakit Layu Bakteri secara In Viv. Aplikasi rhizobakteri mampu menekan kejadian penyakit pada 1 dan 2 MSA. Aplikasi rhizobakteri berpengaruh nyata terhadap persentase kejadian penyakit pada 3 hingga 5 MSA (Tabel 2). Isolat EPT 9 mampu menekan kejadian penyakit layu bakteri paling baik dibandingkan dengan isolat lainnya pada 5 MSA.

Kemampuan tersebut diduga karena isolat EPT 9 mampu berkolonisasi di sekitar akar tanaman dan mampu berkompetisi dengan bakteri rhizosfer di sekitar perakaran tanaman. Bakteri antagonis yang mampu bertahan pada kondisi lapang merupakan bakteri yang mampu beradaptasi maupun berkompetisi dengan bakteri rhizosfer di lingkungan tersebut [18]. Selain itu, isolat EPT 9 juga memiliki kemampuan PGP yang dapat meningkatkan induksi ketahanan sistemik terhadap patogen. Bakteri yang dapat menekan kejadian penyakit juga menghasilkan senyawa berupa lipopolisakarida, siderofor dan asam salisilat untuk menginduksi ketahanan sistemik menghambat pertumbuhan penyakit [19].

Tabel 2. Persentase kejadian penyakit layu bakteri

\begin{tabular}{cccccc}
\hline Kode & \multicolumn{4}{c}{ Persentase kejadian penyakit (MSA) \pm SD } \\
\cline { 2 - 6 } Perlakuan & 1 & 2 & 3 & 4 & 5 \\
\hline P1 (akuades) & $5,00 \pm 5,77$ & $10,00 \pm 8,16$ & $17,50 \pm 5,00^{\mathrm{b}}$ & $30,00 \pm 0,00^{\mathrm{b}}$ & $45,00 \pm 12,91^{\mathrm{f}}$ \\
$\quad$ P2 & $2,50 \pm 5,00$ & $5,00 \pm 5,77$ & $5,00 \pm 5,77^{\mathrm{a}}$ & $15,00 \pm 10,0^{\mathrm{a}}$ & $30,00 \pm 8,16^{\mathrm{d}}$ \\
(bakterisida) & & & & & \\
P3 (isolat & $0,00 \pm 0,00$ & $0,00 \pm 5,00$ & $7,50 \pm 5,00^{\mathrm{a}}$ & $17,50 \pm 5,00^{\mathrm{a}}$ & $25,00 \pm 12,91^{\mathrm{b}}$ \\
AGR 1) & & & & & \\
P4 (isolat & $0,00 \pm 0,00$ & $2,50 \pm 5,00$ & $7,50 \pm 5,00^{\mathrm{a}}$ & $15,00 \pm 10,00^{\mathrm{a}}$ & $27,50 \pm 12,58^{\mathrm{c}}$ \\
AGR 2) & & & & & \\
P5 (isolat & $0,00 \pm 0,00$ & $2,50 \pm 5,00$ & $7,50 \pm 5,00^{\mathrm{a}}$ & $12,50 \pm 5,00^{\mathrm{a}}$ & $30,00 \pm 8,16^{\mathrm{d}}$ \\
$\quad$ EPT 8) & & & & & \\
P6 (isolat & $0,00 \pm 0,00$ & $5,00 \pm 5,77$ & $5,00 \pm 5,77^{\mathrm{a}}$ & $10,00 \pm 8,20^{\mathrm{a}}$ & $20,00 \pm 18,26^{\mathrm{a}}$ \\
\hline
\end{tabular}




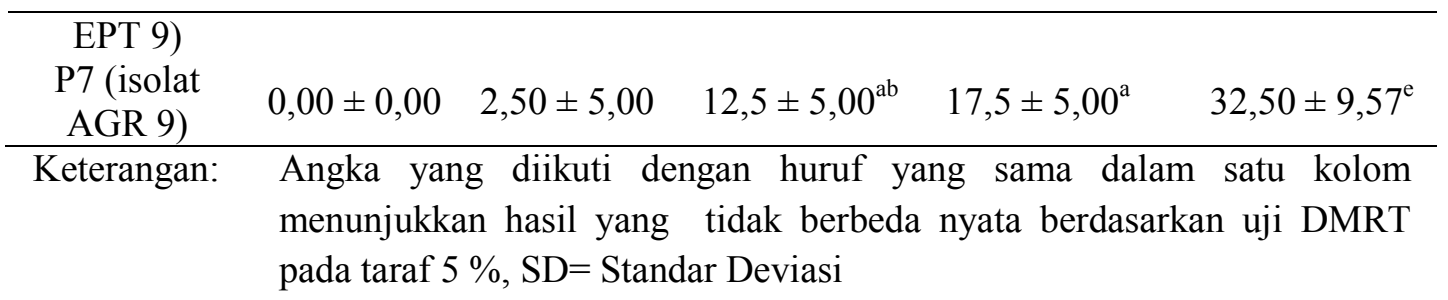

Aplikasi bakteri rhizosfer meningkatkan rerata tinggi tanaman kentang pada 1 MSA (Gambar 1). Isolat AGR 1, AGR 2, EPT 8 dan EPT 9 mampu meningkatkan tinggi tanaman yang sama dari bakterisida pada 1 MSA. Peningkatan pertumbuhan tinggi tanaman oleh bakteri rhizosfer dapat dikarenakan isolat tersebut memiliki sifat sebagai biostimulator atau pemicu pertumbuhan tanaman. Bakteri memiliki kemampuan meningkatkan dalam pertumbuhan dan produksinya tanaman karena memproduksi hormon IAA serta membantu secara bertahap dalam mengembalikan kesuburan tanah [20].

Jumlah Daun. Berdasarkan diagram (Gambar 2) menunjukkan isolat EPT 9 dapat menghasilkan jumlah daun lebih banyak dibandingkan bakterisida. Isolat EPT 9 meningkatkan jumlah daun hingga 19,6\% pada 1 MSA dan 20,4 \% pada saat 2 MSA daripada bakterisida. Peningkatan jumlah daun tersebut menunjukkan bahwa, penggunaan bakteri rhizosfer berdampak positif pada pertumbuhan tanaman karena meningkatkan populasi bakteri sebagai biofertilizer dalam tanah [20].

Tinggi tanaman. Tinggi tanaman pada pengamatan 5 MSA mengalami penurunan pertumbuhan yang dipengaruhi oleh intensitas penyakit yang tinggi. Keberadaan bakteri patogen dalam tanaman kentang mengakibatkan pertumbuhan tunas tanaman kentang terhambat. Patogen tersebut dapat menghambat aliran air dan nutrisi yang masuk ke dalam jaringan tanaman. Patogen mengkolonisasi dalam jaringan tanaman untuk memperoleh nutrisi dari tanaman. Nutrisi yang diperoleh bakteri patogen berupa polimer pektin sehingga, populasi patogen meningkat dengan cepat [21].

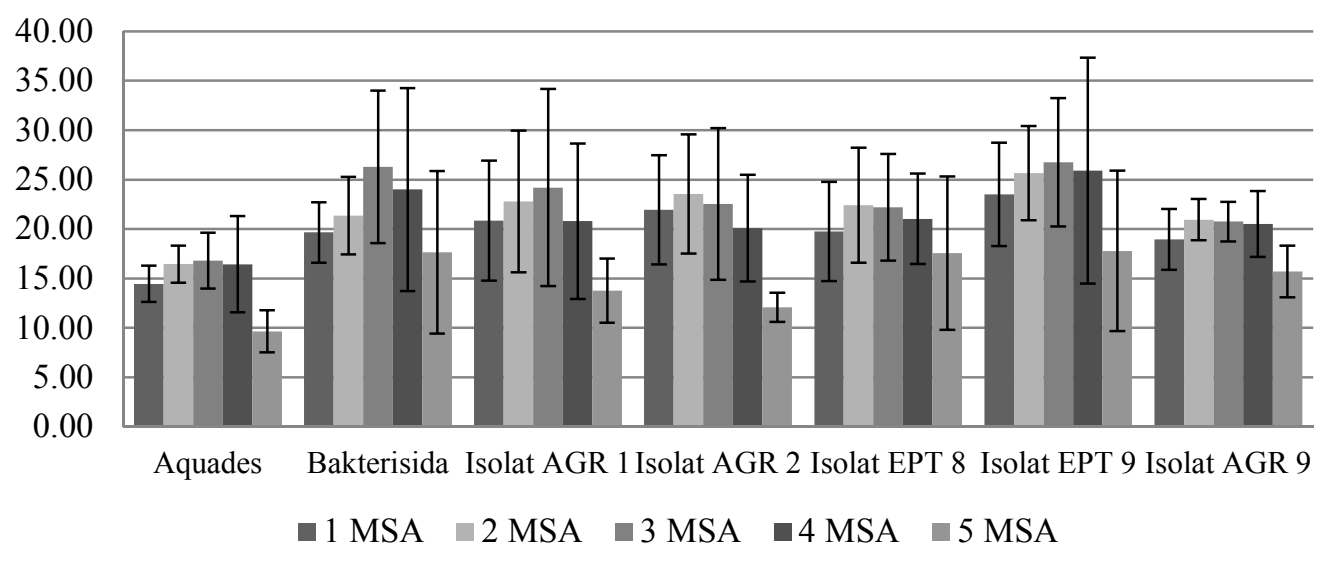

Gambar 3. Rerata jumlah daun tanaman kentang 


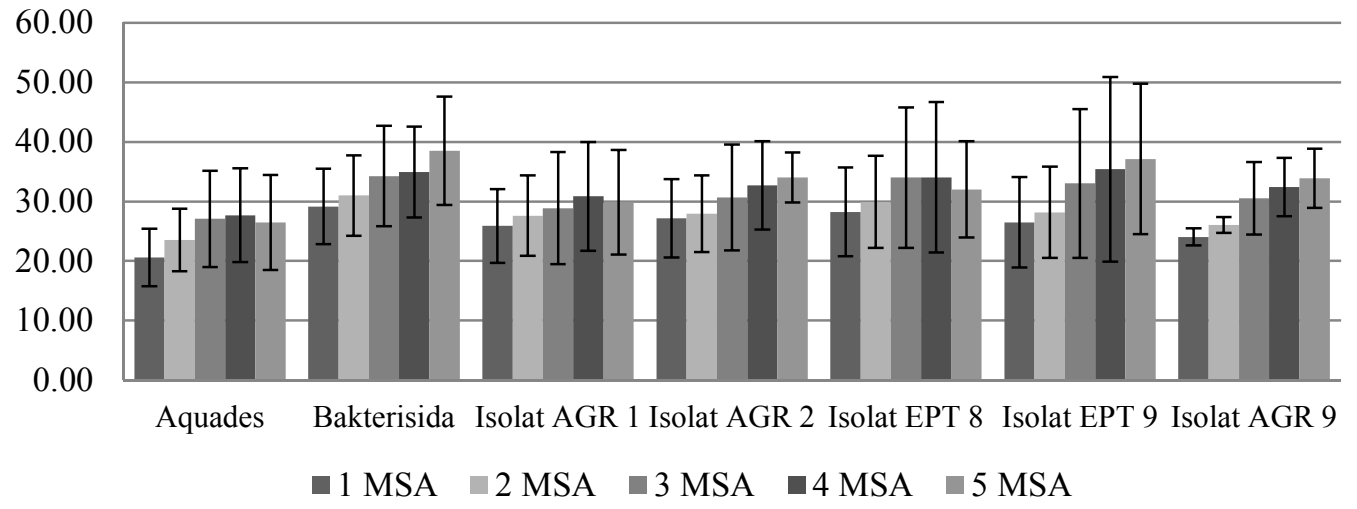

Gambar 4. Rerata tinggi tanaman

Berat Umbi. Aplikasi bakteri rhizosfer mampu meningkatkan berat umbi kentang dibandingkan dengan perlakuan kontrol akuades. Rerata umbi kentang pada isolat AGR 2, EPT 8, EPT 9 lebih tinggi dibandingkan dengan perlakuan bakterisida (Tabel 3).

Tabel 3. Rerata berat umbi kentang

\begin{tabular}{ll}
\hline Kode perlakuan & $\begin{array}{l}\text { Rerata berat umbi } \\
\text { kentang (gram) } \\
\text { SD }\end{array}$ \\
\hline P1 (akuades) & $141,05 \pm 75,20^{\mathrm{a}}$ \\
P2 (bakterisida) & $238,51 \pm 104,1^{\mathrm{ab}}$ \\
P3 (isolat AGR 1) & $203,60 \pm 58,90^{\mathrm{ab}}$ \\
P4 (isolat AGR 2) & $328,70 \pm 117,9^{\mathrm{b}}$ \\
P5 (isolat EPT 8) & $320,65 \pm 122,6^{\mathrm{b}}$ \\
P6 (isolat EPT 9) & $346,75 \pm 37,30^{\mathrm{b}}$ \\
P7 (isolat AGR 9) & $253,70 \pm 83,40^{\mathrm{ab}}$ \\
\hline
\end{tabular}

Keterangan: Angka yang diikuti dengan huruf yang sama menunjukkan hasil yang tidak berbeda nyata berdasarkan uji DMRT pada taraf $5 \%$.
Isolat EPT 9 merupakan isolat yang memiliki angka kejadian penyakit yang rendah dan menghasilkan jumlah daun yang lebih banyak dibandingkan aplikasi bakterisida. Kemampuan isolat EPT 9 tersebut dikarenakan adanya aktivitas PGP berupa penambat nitrogen dan pelarut fosfat. Nitrogen maupun fosfat merupakan makronutrien yang dibutuhkan oleh tanaman, yang merupakankomponen esensial seperti asam amino, asam nukleat, ATP dan NADH [22].

Isolat bakteri rhizosfer mampu meningkatkan produksi umbi dan rerata jumlah daun tanaman kentang dibandingkan perlakuan akuades. Peningkatan tesebut dikarenakan adanya kolerasi antara jumlah daun dengan jumlah produksi umbi kentang. Peningkatan indeks luas daun memungkinkan terjadinya proses fotosintesis yang lebih baik sehingga menghasilkan asimilat yang lebih tinggi untuk pertumbuhan tanaman [23].

Identifikasi Bakteri. Berikut ini merupakan hasil pengujian secara fisiologis pada bakteri antagonis:

Tabel 4. Karakterisasi isolat bakteri rhizosfer

\begin{tabular}{|c|c|c|c|c|c|}
\hline Karakterisasi & AGR 1 & AGR 2 & EPT 8 & EPT 9 & AGR 9 \\
\hline Pengujian $\mathrm{KOH}$ & $\mathrm{B}$ & B & TB & TB & $\mathrm{B}$ \\
\hline Pengujian Gram & - & - & + & + & - \\
\hline Pewarnaan spora & TD & TD & + & + & TD \\
\hline Bentuk & Basil & Basil & Basil & Basil & Basil \\
\hline $\begin{array}{l}\text { Uji Oksidatif } \\
\text { fermentatif }\end{array}$ & Oksidatif & Oksidatif & Fermentatif & Fermentatif & Fermentatif \\
\hline $\begin{array}{l}\text { Pertumbuhan } \\
\text { pada media YDC }\end{array}$ & - & + & TD & TD & + \\
\hline Pertumbuhan & - & + & TD & TD & TD \\
\hline
\end{tabular}




\begin{tabular}{|c|c|c|c|c|c|}
\hline $\begin{array}{l}\text { pada media } \\
\text { King's B }\end{array}$ & & & & & \\
\hline $\begin{array}{l}\text { Pertumbuhan } \\
\text { pada media YDC } \\
\text { suhu } 33^{\circ} \mathrm{C}\end{array}$ & + & $\mathrm{TD}$ & $\mathrm{TD}$ & TD & TD \\
\hline Genus & Xanthomonas & Pseudomonas & Bacillus & Bacillus & Pantoea \\
\hline
\end{tabular}

Hasil pengujian in vitro didapatkan isolat terbaik yaitu isolat AGR 2 dan isolat EPT 9 mempunyai kejadian penyakit paling rendah pada pengujian in vivo. Berdasarkan hasil analisis kuantitatif DNA (Tabel 5), isolat bakteri AGR 2 maupun EPT 9 menunjukkan nilai kemurnian DNA yang tinggi. Kemurnian DNA memiliki rasio lebih dari 1,8 pada panjang gelombang $\lambda 260-\lambda 280 \mathrm{~nm}$. Selain itu, ditunjukkan dengan hasil visualisasi berupa pita DNA hasil PCR yang tebal dan terang oleh sampel DNA kedua bakteri yang diisolasi (Gambar 3). Sampel DNA yang tervisualisasikan sebagai pita yang terang dan tebal memiliki konsentrasi dan tingkat kemurnian tinggi.

Tabel 5. Hasil pengukuran sampel DNA secara kuantitatif

\begin{tabular}{lllll}
\hline $\begin{array}{l}\text { Nama } \\
\text { isolat }\end{array}$ & $\begin{array}{l}\text { Konsentrasi } \\
(\mathrm{ng} / \mu \mathrm{l})\end{array}$ & $\begin{array}{l}\mathrm{A} 260 \\
/ 280\end{array}$ & $\begin{array}{l}\mathrm{A} 260 / 2 \\
30\end{array}$ & $\begin{array}{l}\text { Vol } \\
(\mu \mathrm{l})\end{array}$ \\
\hline AGR 2 & 402,2 & 1,92 & 2,44 & 30 \\
EPT 9 & 131,5 & 1,88 & 2,48 & 30 \\
\hline
\end{tabular}

Pengukuran konsentrasi hasil isolasi DNA bakteri didasarkan pada perbandingan relatif dengan konsentrasi marker DNA yang digunakan. Berdasarkan hasil kemiripan sekuens pada gen bank sekuen gen 16S rRNA isolat AGR 2 menunjukkan 99\% identik dengan Pseudomonas aeruginosa, sedangkan isolat EPT 9 menunjukkan $100 \%$ identik dengan Bacillus cereus.

\section{KESIMPULAN}

Bakteri hasil eksplorasi di rhizosfer UB Forest didapatkan 20 isolat yang bersifat antagonis dari 38 isolat bakteri rhizosfer. Dua isolat yang teridentifikasi sebagai $P$. aeruginosa dan $B$. cereus berpotensi sebagai agens antagonis penyakit layu bakteri pada tanaman kentang. Hasil in vitro maupun in vivo menunjukkan aplikasi bakteri rhizosfer memengaruhi hasil berat umbi kentang dan penurunan angka kejadian penyakit yang lebih baik dibandingkan dengan bakterisida.

\section{UCAPAN TERIMAKASIH}

Penelitian ini terlaksana atas Pendanaan program Indofood Riset Nugraha tahun 20172018. Penulis menyampaikan ucapan terima kasih pada para sahabat yang telah membantu dalam penelitian. Ucapan terimakasih juga tertuju untuk teman-teman laboratorium Bakteriologi yang telah membantu pekerjaan di laboratorium.

\section{DAFTAR PUSTAKA}

[1] Kiloes, A.M., A.L. Sayekti, and M.J. Anwarudin. Evaluasi Daya Saing Komoditas Kentang di Sentra Produksi Pangalengan Kabupaten Bandung (Potato Competitiveness Evaluation in Production Center of Pangalengan, Bandung Regency). Jurnal Hortikultura. 25 (1): 88-96

[2] Food and Agriculture Organization. 2014. The State of Food Insecurity in the World 2014: Strengthening the Enabling Environment for Food Security and Nutrition.Rome: Food and Agriculture Organization of the United Nations; Available at: www.fao.org

[3] Asgar, A., S.T. Rahayu, Kusmana and Sofiari. 2011. Uji Kualitas Umbi Beberapa Klon Kentang untuk Keripik. Jurnal Hortikulura. 21 (1): 51-59

[4] Maheshwari, D. K., and M. Saraf. 2013. Bacteria in Agrobiology: Crop Productivity. Berlin (DE). Springer

[5] Pande, A., P. Prashant, M. Simhi and S. Mritunjay. 2017. Phenotypic and Genotypic Characterization of Phosphate Solubilizing Bacteria and Their Efficiency on the Growth of Maize. Journal of Genetic Engineering and Biotechnology. 15: 379391

[6] Ramesh, R., and P.S. Gauri. 2012. Rhizosphere and Endophytic Bacteria for the Suppression of Eggplant Wilt caused by 
Ralstonia solanacearum. Journal Crop Protection. 37: 35-41

[7] Kawaguchi, A., K. Inoue and Y. Ichinose. 2008. Biological Control of Crown Gall of Grapevine, Rose, Tomato by Nonpathogenic Agrobacterium vitis Strain VAR03-1. Journal Phytopathology. 98 (11): 1218-12250

[8] Prasad, J.K., S.K. Gupta, and R. Raghuwanshi. 2017. Screening Multifunctional Plant Growth Promoting Rhizobacteria Strains for Enhancing Seed Germination in Wheat (Triticum aestivum L.). International Journal of Agricultural Research. 12 (2): 64-72

[9] Yanti, Y., F.F. Astuti, T. Habazar, C.R. Nasution. 2017. Screening of Rhizobacteria From Rhizosphere of Healthy Chili to Control Bacterial Wilt Disease and to Promote Growth And Yield of Chili. Biodiversitas. 18 (1): 1-9

[10] Yuliati, A. E. 2008. Ketahanan Klon Kentang Liar (Solanum chacoense) Terhadap Penyakit Layu Bakteri (Ralstonia solanacearum) Secara In Vitro dan di Lapangan. Tesis. Institut Pertanian Bogor

[11] Holt, J.G., N. R. Krieg, P. H. Sneath, J. T. Staley and S. T. Williams. 1994. Bergey's Manual of Determinative Bacteriology 9th Edition. Williams and Wilkins Baltimore. USA

[12] Schaad, N., and W. Chun. 2001. Laboratory Guide for Idetification of Plant Pathogenic Bacteria. 3rd Edition. APS Press. St. Paul Minnessota

[13] Mahdy, A. M., G.M. El-Habba, F.G. Mohamed and A.A. Badr. 2012. Virulence of Ralstonia solanacearum the Causal of Potato Brown Rot Disease Under Egyptian Conditions. Annals of Agricultural Sciences Journal. 50 (1): 59-67

[14] Goenadi, D., I. Siswieto, and Y. Sugiarto. 2000. Bioactivation of Poorly Soluble Phosphate Rocks with a Phosporus Solubilizing Fungus. Journal of Soil Science. 4: 409-412

[15] Ramamoorthy, V., and P. Samiyapn. 2001. Induction of Defense Related Genes in Pseudomonas fluorescens treated Chili Plants in Response to Infection by Colletotrichum capsici. Journal of Mycology Plant Pathology. 45: 55-63
[16] Agrios, G. N. 2004. Plant Pathology 5th Edition. New York: Elsevier Academic Press

[17] Dong, Y., J. Xu, X. Liu, and L. Zhang. 2000. An Enzyme that Inactivates the Acyhomoserine Lactone Quorum-Sensing Signal and Attenuates the Virulence of Erwinia carotovora. Proceedings National Academy Science. 97: 3526-3531

[18] Lugtenberg, B. J. J., L. Dekkers. and G.V. Bloemberg. 2001. Molecular Determinants of Rhizosphere Colonization by Pseudomonas. Annual Review Phytopathology. 39:461-490

[19] Chandrasekaran, M., D. Subramanian, E. Yoon, T. Kwon, and S. Chun. 2016. Metaanalysus Reveals that the Genus Pseudomonas Can Be a Better Choice of Biological Control Agent against Bacterial Wilt Disease Caused by Ralstonia solanacearum. Plant Pathology Journal. 32(3): 216-227

[20] Widawati, S., Suliasih and Saefudin. 2015. Isolasi dan Uji Efektivitas Plant Growth Promoting Rhizobacteria di Lahan Marginal pada Pertumbuhan kedelai var. Wilis. Prosiding Seminar Masyarakat Biodiversitas Indonesia, 1(1): 59-65

[21] Arwiyanto, T. 2013. Ralstonia solanacearum Biologi, Peyakit yang Ditimbulkan, dan Pengelolaannya. Yogyakarta: Gadjah Mada University Press

[22] Orhan, F. 2016. Alleviation of Salt Stress by Halotolerant and Halophilic Plant Growth Promoting Bacteria In Wheat (Triticum aestivum). Brazilian Journal of Microbiology. 47 : 621-627

[23] Arifin, M., A. Nugroho, and A. Suryanto. 2014. Kajian Panjang Tunas dan Bobot Umbi Bibit terhadap Produksi Tanaman Kentang (Solanum tuberosum L.) Varietas Granola. Jurnal Produksi Tanaman. 2 (3): 221-229 